\title{
Gaya Kepemimpinan Kepala Yayasan Dalam Meningkatkan Kinerja Guru TK Nur Iman Palembang
}

\author{
Karliana Indrawari \\ Institut Agama Islam Negeri (IAIN) Curup \\ karlianaindrawari@iaincurup.ac.id \\ Azwar Hadi \\ Universitas Muhammadiyah Palembang \\ azwarhadiump1971@gmail.com
}

\begin{abstract}
Principals in Nur Iman Kindergarten are required to have a concern for the problems faced by students. The head of the foundation has functions as supervisors, leaders, teaching staff, and school administration. The purpose of this research is to find out the leadership style of the foundation bead in improving teacher performance and education processing in Nur Iman Kindergarten, to find out the foundation head's achievements in improving teacher performance and educational processing in Nur Iman Kindergarten, and to find out the supporting factors and obstacles to the foundation head's leadership style in improving teacher performance and education processing in Nur Iman Kindergarten. The research method is field study research. Data collection techniques use observation, interviews and documentation. Data analysis techniques using miles and buberman, namely data reduction, data presentation, and data conclusions. The results showed that the head of the foundation had maximized the performance of teachers in Nur Iman Kindergarten.
\end{abstract}

Keywords: Leadership Style, Teacher Performance

\begin{abstract}
Abstrak : Kepala sekolah di TK Nur Iman dituntut untuk memiliki kepedulian terhadap permasalahan yang dihadapi peserta didik. Kepala yayasan memiliki fungsi sebagai pengawas, pemimpin, tenaga pendidik, dan administrasi sekolah. Tujuan dalam penelitian adalah untuk mengetahui gaya kepemimpinan kepala yayasan dalam meningkatkan kinerja guru dan pengolahan pendidikan di TK Nur Iman, untuk mengetahui capaian kepala yayasan dalam meningkatkan kinerja guru dan pengolahan pendidikan di TK Nur Iman, dan untuk mengetahui faktor pendukung dan penghambat gaya kepemimpinan kepala yayasan dalam meningkatkan kinerja guru dan pengolahan pendidikan di TK Nur Iman. Metode penelitian adalah field study research. Tekhnik pengumpulan data menggunakan observasi, wawancara dan dokumentasi. Tekhnik analisa data menggunakan miles and huberman yaitu reduksi data, penyajian data, dan kesimpulan data. Hasil penelitian menunjukkan bahwa kepala yayasan telah maksimal dalam meningkatkan kinerja guru di TK Nur Iman.
\end{abstract}

Kata Kunci: Gaya Kepemimpinan, Kinerja Guru

\section{Pendahuluan}

Pendidikan adalah upaya yang dilakukan orang dewasa atau guru baik terncana maupun sengaja dalam meningkatlan suasana atau lingkungan belajar yang kondusif, agar peserta didik dapat menumbuh dan mengembangkan potensi baik potensi spritual, potensi akademik, kepribadian, dan keterampilan lainnya. Pendidikan diterapkan di lembaga formal, informal, maupun informal. 
Contoh lembaga pendidikan yang ada di Indonesia adalah dari jenjang TK/RA, SD/MI, SMP/MTs, SMA/MA, dan Perguruan Tinggi dari S1, S2 dan S3.

Dalam mewujudkan tujuan dari lembaga pendidikan, sekolah membentuk dan menciptakan sumber daya manusia yang berkualitas, mandiri, dan dapat bersaing di era globalisasi. Sekolah dituntut untuk melaksanakan proses pembelajaran dengan terarrah, tertib, dan berkelanjutan.

Lembaga pendidikan terkhusus sekolah bertujuan menghasilan siswa dan alumni yang berkualitas dalam segala bidang. Kualitas pendidikan diukur dari kualitas siswa dan kualitas guru. Mutu hasil pendidikan ditentukan dari kinerja guru, kemampuan professional guru, kesejahteraan yang didapat oleh guru, disiplin kerja, motivasi mengjar, serta sarana prasarana sekolah, dan pengelolaan sekolah yang baik dari pimpinan sekolah.

Pemimpin sekolah bisa diketuai oleh kepala sekolah atau kepala yayasan. Kepala yayasan atau kepala sekolah memiliki jabatan dan berperan penting dalam proses pendidikan. Jabatan dan peran darikepala sekolah atau kepala yayasan adalah pengelola pendidikan dan pemimpin formal disekolah (Ara Hidayat dan Imam Machali, 2012).

Berjalannya proses pembelajaran yang baik dan pengelolaan sekolah yang baik tergantung dari tanggungjawab atau manajemen pendidikan yang dilakukan oleh kepala yayasan. Kepala yayasan menciptakan kondisi dan suasana iklim kerja yang baik bahkan hubungan antar manusia di sekolah sekolah terjalin dengan baik (Mulyasa, 2005).

Gaya kepemimpinan dari kepala yayasan dalam melaksanakan tanggungjawab dalam mengelola organisasi adalah koordinasi, kerjasama, keprcayaan, dan kejujuran. Gaya kepemimpinan dalam mengelola sekolah sangat menentukan tinggi atau lemahnya kualitas organisasi yang dipimpinnya.

TK Nur Iman merupakan salah satu sekolah swasta. Dalam aktivitas disekolah, kepala sekolah di TK Nur Iman dituntut untuk memiliki kepekaan terhadap semua permasalahan sekolah baik dari guru, peserta didik, sarana prasarana dan staf-staf di sekolah. Kepala yayasan memiliki fungsi sebagai administrator, manager (pemimpin), supervisor (pengawas), dan sebagai pendidik, dalam merancang dan mengkonsep program sekolah yang rapi dan terencana (Buku panduan Akademik SDIT insan Mulia Wonosobo Tabun pelajaran 2014/2015.). Berangkat dari pemaparan diatas, peneliti tertarik untuk mengadakan penelitian yang fokus pada gaya kepemimpinan kepala yayasan dalam meningkatkan kinerja pendidik di TK Nur Iman.

Identifkasi masalah dalam penelitian adalah: 1) Gaya kepemimpinan yayasan dalam meningkatkan kinerja guru dalam proses mendidik peserta didik atau siswa/i yang sesuai dengan visi dan misi yayasan; 2) adanya anggapan dari pemimpin yayasan bahwa hubungan antara guru dengan peserta didik itu berpengaruh terhadap perkembangan jiwa anak sehingga kinerja guru menjadi 
lebih mudah; 3) kurangnya kedekatan emosional antara pemimpin yayasan dengan guru yang tidak terkontrol juga bisa mempengaruhi kenerja pemimpin dalam TK Nur Iman; 4) masalah yang dihadapai guru juga bisa dibawa ketika mengajar dalam hal ini apa yang dilakukan pemimpin dalam mengatasi hal tersebut.

Tujuan penelitian ini untuk mengetahui bagaimana gaya kepala yayaysan dalam meningkatkan kinerja guru dan pengelolaan pendidikan di TK Nur ziman, untuk mengetahui bagaimana capaian kepala Yayasan dalam meningkatkan kinerja guru dan pengelolahan pendidikan di TK Nur Iman, dan untuk mengetahui bagaimana factor pendukug dan factor penghambat gaya kepemimpinan kepala yayasan dalam meningkatkan kinerja guru dan pengelolaan pendidikan di TK Nur Iman.

Penelitian Khurrota A'yun' tesis yang berjudul “Gaya Kepemimpinan Kepala Yayasan. Adapun hasil dari penelitian ini adalah gaya kepemimpinan kepala yayasan SMA 3 Yogyakarta cenderung ke Arah eksekutif. Hal ini dapat dilihat dari apa yang dilakukan ketua yayasan, seperti mampu menjadi motivasi Yang baik untuk bawahannya, dengan memberikan contoh atau keteladanan kedisiplinan dalam bekerja, memberikan bimbingan dan menyapa siswa secara langsung. Dalam menyelesaikan tugas-tugas seperti menentukan lokasi waktu bekerja, pelaksanaan program-program peningkatan mutu diantaranya klinik mata pelajaran, PPI dan pelatihan bahasa asing ketua yayasan dibantu beberapa guru dan karyawan sebagai tim yang bekerja. Kepala yayasan dalam memimpin

Metode penelitian adalah field study research. Tekhnik pengumpulan data menggunakan observasi, wawancara dan dokumentasi. Tekhnik analisa data menggunakan miles and huberman yaitu reduksi data, penyajian data, dan kesimpulan data.

\section{Hasil dan Pembahasan}

Upaya pemimpin TK Nur Iman dalam meningkatkan kinerja guru adalah membimbing guru supaya bersikap profesional, sehigga kegiatan belajar dapat berjalan dengan baik. Meningkatnya profesionalitas guru dapat dilihat dari penilaian wali murid dan guru lainnya. Kepala yayasan sebagai pemimpin diorganisasi harus mampu memobilisasikan sumber daya yayasan terutama guru, dalam kaitannya perencana dan pengevaluasi program yayasan, mengembangkan kurikulum dan pembelajaran, menyediakan sarana dan prasarana, pengelolaan administrasi dan pelayanan siswa, hubungan sekolah dengan masyarakat sekitar dan tentunya dalam penciptaan iklim sekolah yang kondusif. Pemimpin berperan aktif dalam menentukan tugas dan tanggung jawab masing-masing bawahannya, dan tetap melakukan pengawasan. Setiap keputusan yang diambil merupakan hasil musyawarah, gaya kepemimpinan ini ditandai dengan pola prilaku tugas tinggi dan pola perilaku tenggang rasa tinggi. 
Usaha yang dilakukan pemimpin jika kinerja guru itu kurang yaitu dengan cara kita panggil guru tersebut dan apa solusi yang baik, kita ajak berdiskusi, sharing dan tanyakan tentang masalahnya apa, masalah pribadi tidak boleh dibawa kesekolah. Seorang pemimpin itu mengajarkan keterampilan kepada guru yang kurang profesional dalam mengajar. Pemimpin harus tegas dalam memberikan pengarahan terhadap guru-guru yang ada disekolah sehingga kinerja guru itu makin meningkat dan sesuai dengan apa yang diinginkan oleh pemimpin yayasan dan juga guru.

Cara ibu yayasan memimpin guru" yang ada di TK Nur Iman adalah memimpin guru-guru itu susah gampang ada yang mau di atur ada yang tidak mau tergantung dari pemimpin. Kalau pemimpin itu tegas maka bawahannya juga akan patuh. Upayakan guru itu tepat waktu datang ke sekolah. Intinya banyak-banyak bertanya kita rangkul guru supaya kekeluargaan kita semakin erat. Kepala yayasan memimpin guru secara langsung pada saat rapat atau pada saat kepala yayasan dikantor guru, karena pembinaan selalu dilakukan secara langsung seperti pada saat mengurus administrasi sekolah.

Fakto-faktor penghambat dan pendukung dalam gaya kepemimpinan kepala yayasan di TK Nur Iman dalam meningkatkan pengelolaan pendidikan dan kinerja pendidik adalah Faktor pendukung : Bantuan dari dinas pendidikan kota Palembang dan Provinsi seperti kesejahteraan guru. Adanya sifat moril yaitu keadaan jiwa dan emosi seseorang yang mempengaruhi kemauan untuk melaksanakan tugas dan akan mempengaruhi hasil pelaksanaan tugas perorangan maupun organisasi. Factor-faktor dalam segi moril adalah a) kepemimpinan kepala sekolah atau Yayasan; b) keyakinan dan kepercayaan akan suatu kebenaran; c) penghargaan atas tuntasnya tugas; d) solidaritas dengan sesame; e) pelatihan dan pendidikan; f) rekreasi dan kesejateraan; g) memberikan kesempatan dalam mengembangkan bakat. Adapun factor penghambat adalah: a) komunikasi sesama atau sama bawahan kurang baik; b) kurang memiliki pemahaman dalam proses komunikasi baik komunikasi formal maupun informal; c) stres. (kepala yayaysan lebih terhadap permasalahan dan stres bawahannya.

Prinsip pemimpin yayasan dalam memimpin guru di yayasan TK Nur Iman adalah 1) Prinsipnya profesional. Guru itu harus profesional, dengan profesionalnya dia mengerti akan keadaan kelas, guru berhak mengatur kelas, guru pendamping bertugas membantu guru inti; 2) prinsip ikhlas dari seorang kepala yayasan adalah suatu tugas dan amanah dari Allah SWT.

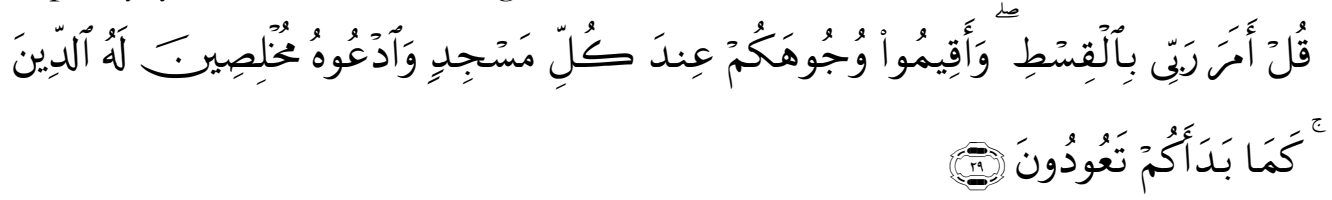


Katakanlah: "Tuhanku menyurub menjalankan keadilan". dan (katakanlab): "Luruskanlah muka (diri)mu[533] di Setiap sembabyang dan sembablah Allah dengan mengikhlaskan ketaatanmu kepada-Nya. sebagaimana Dia telah menciptakan kamu pada permulaan (demikian pulalah kamu akan kembali kepadaNya)". (disarikan dari Tim Sahifa, Al-Qur'an dan Terjemahan, (Sahifa, 2017).

3) Prinsip jujur yang dimiliki oleh seorang kepala Yayasan menjadi tauladan bagi guru-guru dan siswa disekolah.

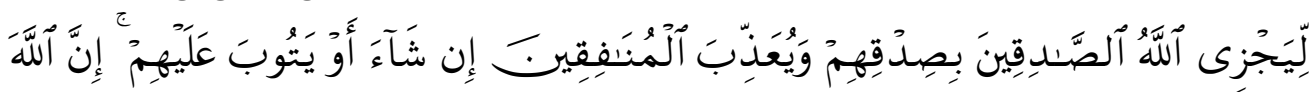

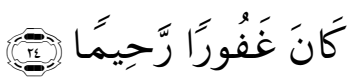

supaya Allah memberikan Balasan kepada orang-orang yang benar itu karena kebenarannya, dan menyiksa orang munafik jika dikehendaki-Nya, atau menerima taubat mereka. Sesunggubnya Allah adalah Maha Pengampun lagi Maha Penyayang. (disarikan dari Tim Sahifa, Al-Qur'an dan Terjemahan, (Sahifa, 2017).

4). Prinsip amanah wajib dimiliki seorang pimpinan karena pertanggungjawabannya didunia dan akhirat.

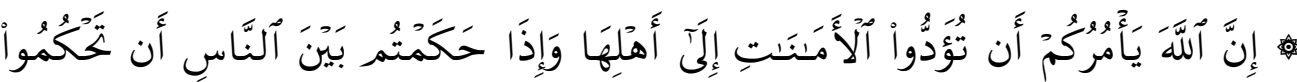

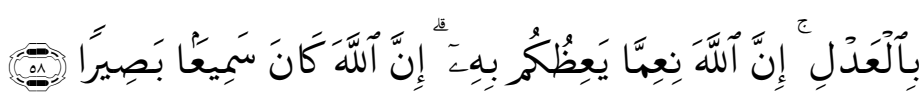

Sesunggubnya Allah menyurub kamu menyampaikan amanat kepada yang berhake menerimanya, dan (menyurub kamu) apabila menetapkan bukum di antara manusia supaya kamu menetapkan dengan adil. Sesunggubnya Allah memberi pengajaran yang sebaik-baiknya kepadamu. Sesunggubnya Allah adalah Maha mendengar lagi Maha melihat. (disarikan dari Tim Sahifa, Al-Quran dan Terjemahan, (Sahifa, 2017).

5). Prinsip adil dalam dunia pendidikan harus ditegakkan seperti pemberian tugas maupun pemberian gaji kepada guru.

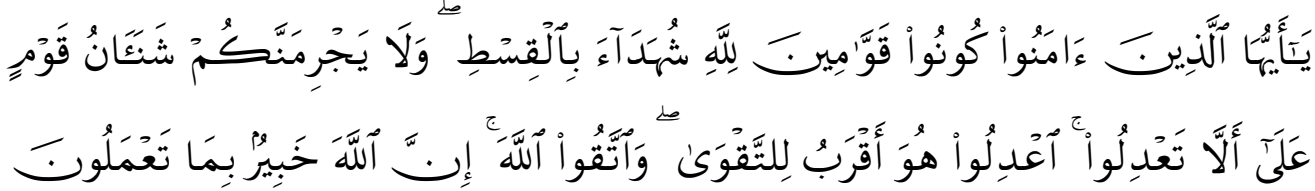

Hai orang-orang yang beriman hendaklah kamu Jadi orang-orang yang selalu menegakkan (kebenaran) karena Allah, menjadi saksi dengan adil. dan janganlah 
sekali-kali kebencianmu terhadap sesuatu kaum, mendorong kamu untuk Berlaku tidak adil. Berlaku adillah, karena adil itu lebih dekat kepada takwa. dan bertakwalah kepada Allah, Sesunggubnya Allah Maha mengetahui apa yang kamu kerjakan. (disarikan dari Tim Sahifa, Al-Qur`an dan Terjemahan, (Sahifa, 2017).

Pemimpin yayasan akan melakukan teguran jika kinerja guru tidak sesuai dengan visi dan misi yayasan TK Nur Iman yaitu apabila tidak sesuai dengan visi an misi TK Nur Iman saya luruskan selaku pemimpin yayasan, intinya mendidik anak supaya anak itu berpengetahuan, berbakat, mandiri dan memiliki kemampuan dasar dan memberikan ilmu pengetahuan teknologi dan perkembangan anak. Meningkatkan profesionalitas tenaga kependidikan, meningkatkan kesehjateran guru dan pegawai serta membimbing guru dan anak didik menjadi anak yang shalih dan shalihah dan membentuk karakter anak yang mandiri.

\section{Penutup}

Kesimpulan dari penelitian adalah Gaya kepemimpinan kepala yayasan TK Nur Iman adalah gaya kepemimpinan demokratis. Ditunjukkan dengan hasil analisis yang telah peneliti lakukan terhadap peran kepala yayasan TK Nur Iman sebagai pemimpin pendidikan. Adapun penjelasannya adalah 1) kepala yayasan memberikan kesempatan kepada guru untuk memberikan pendapat dan saran untuk kemajuan sekolah; 2) kepala yayasan berusaha mensamaratakan antara kepentingan dan tujuan kelompok dan organisasi dari kepentingan dan tujuan pribadi; 3) kepala yayasan menerima saran-saran dan kritikan dari guru-guru; 4) kepala yayasan menerapkan timwrok dan kerjasama dilingkungan TK Nur Iman; 5) kepala yayasan memberikan kesempatan kepada guru-guru memperbaiki kesalahan mereka; 6) kepalayayasan mengembangkan kualitas dan kekampuan guru-guru di TK Nur Iman.

Gaya kepemimpinan demokratis kepala yayasan TK Nur Iman terbukti cukup berhasil dalam meningkatkan kinerja pendidik dan pengelolaan pendidikan di TK Nur Iman. Hal ini dapat dilihat dari kinerja pendidik dan pengelolaan pendidikan yang semakin baik serta tata tertib yang telah dibuat di taati dan dilaksanakan oleh guru-guru dan staf. Namun memang ada beberapa hal yang kurang yaitu tentang pendidik yang masih belum semuanya bisa mengembangkan keprofesionalan dengan sikap reflektif dan belum adanya karya ilmiah dari pendidik. Hal ini diakibatkan karena usia yang masih muda dan pengalaman mengajar yang belum banyak. Hal ini adalah mengenai pengelolaan gedung perpustakaan yang masih belum memadahi untuk dijadikan perpustakaan, disebabkan karena pedanaan yang hanya pas-pasan.

Dalam menjalankan perannya sebagai kepala yayasan dengan demokratisnya, tentu saja ada faktor pendukung dan penghambat yang melatarbelakangi. Faktor pendukung meliputi Strenghts (kekuatan) dan 
Opportunities (peluang). Strenghts (kekuatan) yaitu kepala yayasan sudah S2, 5 pendidik sedang proses S2, buku perpustakaan memadai, kepala yayasan memiliki pengalaman mengenal TK Nur Iman, akreditasi sekolah B, sisitem fullday school, Manajemen sekolah cukup bagus, menggunakan kurikulum K13, buku penghubung dengan orangtua, target pencapaian lulusan bisa membaca, menulis, mewarnai dan berhitung, adanya dapur logistik serta pembinaan pendidik, tenaga kependidikan dan pesrta didik.

Saran dalam penelitian ini adalah 1) Kepala yayasan selalu berusaha mengadakan pelatihan atau workshop dalam meningkatkan kualitas dan kompetensi guru baik dari aspek social, kepribadian, professional, dan paedagogik, terutama dalam penulisan karya ilmiah bagi guru serta merubah jadwal rapat seminggu sekali; 2) guru bisa meningkatkan kualitas dirinya melalui pelatihan atau seminar.

\section{Daftar Pustaka}

Ara Hidayat dan Imam machali. 2012. Pengelolaan Pendidikan: Konsep, Prinsip dan Aplikasi dalam Mengelola Sekolah dan Madrasah. Yogyakarta: Kaukaba.

Arif, M. (2019). Hubungan Budaya Akademik dan Budaya Organisasi dengan Kinerja Guru. Tadbir : Jurnal Studi Manajemen Pendidikan, 3(1), 1737. doi:http://dx.doi.org/10.29240/jsmp.v3i1.804

Buku panduan Akademik SDIT insan Mulia Wonosobo Tahun pelajaran 2014/2015.

Dirawat dkk. 1983, Pengantar Kepemimpinan. Surabaya: Usaha Nasional.

E.Mulyasa. 2005. Menjadi Kepala Yayasan Profesional: dalam Konteks Menyukseskan MBS dan KBK. Bandung: PT Remaja Rosdakarya.

Emzir. 2008. Metodologi Penelitian Pendidikan Kuantitatif dan Kualitatif . Jakarta: Raja Grafindo persada.

Fathurrochman, I. (2017). Pengembangan kompetensi pegawai aparatur sipil negara (ASN) Sekolah Tinggi Agama Islam Negeri (STAIN) Curup [The development of the competency of the state civil servant (ASN) STAIN Curup]. Manajer Pendidikan, 11(21), 120-129.

Fathurrochman, I., Budiman, D. A., Alamsyahril, \& Kristiawan, M. (2019). Revitalization Management Of Islamic Boarding School Preventing The Radicalism. Restaurant Business, (10), 495-505. Retrieved from https://journals.eduindex.org/index.php/rb/article/view/9462

Husaini Usman dan Purnomo Setiady Akbar. 2000. Metodologi Penelitian Sosial. Jakarta: Bumi Aksara.

Muwahid Shulhan. 2013. Model Kepemimpinan Kepala Madrasah dalam Meningkatkan Kinerja Guru. Yogyakarta: Teras.

Nana Sudjana Ibrahim. 2000. Penelitian dan Penelitian Pendidikan. Bandung: Sinar Baru. 
Ristianti, D. H., Danim, S., Winarto, H., \& Dharmayana, I. W. (2019). The Development Of Group Counselling Assessment Instruments. International Journal of Scientific \& Technology Research, 8(10), 267272. Retrieved from http://www.ijstr.org/paperreferences.php?ref=IJSTR-1019-23814

Sugiyono. 2010. Metode Penelitian Pendidikan. Bandung: Alfabeta.

Sulistyorini, 2001. Hubungan antara Manajerial kepala sekolah dan Iklim Organisasi dengan kinerja Guru, jurnal Ilmu Pendidikan, Th 28 no. 1 januari 2001.

Sutrisno Hadi. 1998. Metodologi Research. Yogyakarta: Andi offset.

Syaoid sukmadinata. 2007. Metode Penelitian Pendidikan. Bandung: Remaja Rosdakarya.

Wahjosumidjo. 2002. Kepemimpinan Kepala Yayasan Tinjauan Teoritik dan Permasalahan, Jakarta: PT, Raja Grafindo Persada. 